Article

\title{
Carbon Stocks and Climate Change: Management Implications in Northern Arizona Ponderosa Pine Forests
}

\section{Benjamin Bagdon * and Ching-Hsun Huang}

School of Forestry, Northern Arizona University, 200 East Pine Knoll Drive, P.O. Box 15018, Flagstaff, AZ 86011, USA; E-Mail: ching.huang@nau.edu

* Author to whom correspondence should be addressed; E-Mail: bab368@nau.edu; Tel.: +1-651-261-6113.

Received: 16 January 2014; in revised form: 18 March 2014 / Accepted: 19 March 2014 /

Published: 4 April 2014

\begin{abstract}
Researchers have observed climate-driven shifts of forest types to higher elevations in the Southwestern US and predict further migration coupled with large-scale mortality events proportional to increases in radiative forcing. Range contractions of forests are likely to impact the total carbon stored within a stand. This study examines the dynamics of Pinus ponderosa stands under three climate change scenarios in Northern Arizona using the Climate Forest Vegetation Simulator (Climate-FVS) model to project changes in carbon pools. A sample of 90 stands were grouped according to three elevational ranges; low- (1951 to $2194 \mathrm{~m})$, mid- (2194 to $2499 \mathrm{~m})$, and high- (2499 to $2682 \mathrm{~m}$.) elevation stands. Growth, mortality, and carbon stores were simulated in the Climate-FVS over a 100 year timespan. We further simulated three management scenarios for each elevational gradient and climate scenario. Management included (1) a no-management scenario, (2) an intensive-management scenario characterized by thinning from below to a residual basal area (BA) of $18 \mathrm{~m}^{2} /$ ha in conjunction with a prescribed burn every 10 years, and (3) a moderate-management scenario characterized by a thin-from-below treatment to a residual BA of $28 \mathrm{~m}^{2} /$ ha coupled with a prescribed burn every 20 years. Results indicate that any increase in aridity due to climate change will produce substantial mortality throughout the elevational range of ponderosa pine stands, with lower elevation stands projected to experience the most devastating effects. Management was only effective for the intensive-management scenario; stands receiving this treatment schedule maintained moderately consistent levels of basal area and demonstrated a higher level of resilience to climate change relative to the two other management scenarios. The results of this study indicate that management can improve
\end{abstract}


resiliency to climate change, however, resource managers may need to employ more intensive thinning treatments than currently proposed to achieve the best results.

Keywords: climate forest vegetation simulator; climate change and elevation; forest carbon stores; forest management and climate change; climate-driven forest mortality; representative concentration pathways

\section{Introduction}

Recent climatic changes have induced shifting forest ecotones and widespread mortality events in the southwestern United States (SW US) [1-5]. Climate in the SW US has become more arid over recent time-scales (i.e., 1970 to present), and this trend is expected to continue into the future [1-6]. Atmosphere-Ocean General Circulation Models (AOGCMs) predict mean annual temperature in the SW US to increase between $2{ }^{\circ} \mathrm{C}$ and $5{ }^{\circ} \mathrm{C}$ in conjunction with an overall decrease in annual precipitation, thus resulting in increased severity and duration of drought-like conditions [4,7]. Warmer, drier conditions in the SW US have been linked to an increased frequency of catastrophic wildfires [4,8,9], bark-beetle outbreaks [4,10], and widespread mortality events [1-6,11]. These amplified rates of tree mortality and extensive mortality events result in large pulses of stored carbon being released into the atmosphere [1,12]. Forests on the Colorado Plateau are part of the largest contiguous span of ponderosa pine (Pinus ponderosa Dougl. Ex Laws) forest in the world and occur across a relatively wide range of elevations (i.e., 1798-3048 m) [13]. It is uncertain how carbon stocks within these forests will respond to different intensities of climate change.

Climate largely dictates the distribution of vegetative communities in the SW US, thus changes in temperature and precipitation regimes can result in landscape-scale alterations of ecosystems [6,14-18]. For example, climate can affect community structure and composition substantially over the range of a couple hundred feet in elevation [2,5,6,14] or over opposite aspects of a hillside [14-16]. Transition zones between forest types are particularly sensitive to changes in annual temperature and precipitation and tend to shift towards northern latitudes and/or higher elevations under warmer, drier conditions [2,5]. Understanding spatial patterns of plant mortality and mortality thresholds for many forest and woodland species in the SW US is still poorly understood [19-21]. Therefore, as climate becomes more arid, shifting ecotones may respond in unexpected ways [19-21]. While drought-induced mortality is an historic disturbance mechanism in the SW US, and many species have developed adaptations to cope with drought $[6,8,19-21]$, the transition to a drier, hotter climate could result in substantial losses of forest carbon stocks over hundreds of thousands of hectares throughout the SW US.

Different climate change intensities should have dissimilar effects across the range of elevations on which ponderosa pine occurs. Earth's current radiative balance is approximately $240 \mathrm{~W} / \mathrm{m}^{2}$, resulting in an average global surface temperature of $15^{\circ} \mathrm{C}[22,23]$. The change in global surface temperature resulting from a $2.6 \mathrm{~W} / \mathrm{m}^{2}$ increase in radiative forcing by year 2100 could be less than $2{ }^{\circ} \mathrm{C}$ depending on climate sensitivity [24]. In contrast, global surface temperature may increase by more than $4.5{ }^{\circ} \mathrm{C}$ with a radiative forcing equal to $8.5 \mathrm{~W} / \mathrm{m}^{2}$ [24]. Regional effects of even a slight change in global 
temperature, i.e., less than $2{ }^{\circ} \mathrm{C}$, are projected to have a stronger impact in the SW US on mean annual temperature (MAT), and perhaps mean annual precipitation (MAP), than in the rest of the United States $[7,25]$. The higher sensitivity of forest species in the SW US is a result of many communities existing at their water-availability limits $[1,4,25]$. Changes in MAP in the SW US are less certain than projections of MAT [7], however, evaporative demand is expected to rise with increases in MAT potentially resulting in massive mortality events [4]. While the link between climate and vegetation has been successfully used to model species distributions [26-28], part of the difficulty in modeling particular stand-level responses to climate change results from the lack of high-resolution, spatial data on historic climate variables [17].

While the relationship between climate and elevation is well established [6,7,14], no study in the SW US to which we are aware has explicitly modeled common stand metrics, such as BA, mortality, or carbon stocks, under climate change at varying elevations. Because the restoration of ponderosa pine forests in Northern Arizona is a top priority for resource managers, an examination of potential differences in stand conditions across elevations and under a changing climate has high practical value. Uncertainty remains as to which stands are most vulnerable to warmer climates. One study suggests that higher-elevation forests in the SW US will experience larger range contractions than lower-elevation stands [29], while other studies propose that lower-elevation forests are at highest risk in a changing climate $[2,5,30]$.

In addition to the risks posed by climate change, many of the ponderosa pine forests on the Colorado Plateau are currently at risk of catastrophic wildfire and hence, large releases of carbon to the atmosphere. Decades of fire suppression and the accumulation of fuel have led to forest conditions that are well outside the natural range of variability [31,32]. Management within these forests prioritizes the return to pre-European settlement conditions through the removal of small-diameter trees and fuels on the forest floor [33]. These "restoration" treatments are typically accomplished through the mechanical removal of small-diameter trees proceeded by a controlled burn [31-33]. Many of the ponderosa pine forests in Northern Arizona are in dire need of fuel-reduction treatments in order to mitigate the risk of catastrophic wildfires [8,31-33]. In some circumstances, thinning treatments on these stands are estimated to result in positive net carbon storage when compared with untreated stands that experience catastrophic wildfire [34-38]. Other studies using benefit-cost analysis have estimated that thinning treatments can result in a positive net present value in the SW US [39-41]. The effectiveness of these management techniques for increasing the stand resilience to specific climate change scenarios remains largely uncertain [42].

Because little is known about these climate/elevation/management interactions, forest managers need an assessment of multiple strategies to mitigate climate change over the range of ponderosa pine forests. The objectives of this study attempt to answer:

1. How might ponderosa pine stands respond to climate change at different elevations?

2. Can management of ponderosa pine forests mitigate the negative effects of climate change on stand mortality and total carbon stocks?

In this study, we used the Climate-Extension to the Forest Vegetation Simulator (Climate-FVS) [43] to predict changes in the conditions and carbon stocks of 90 ponderosa pine stands in Northern Arizona over a 100 year time-span. Before detailing the Climate-FVS model, we first 
introduce the next generation of climate change scenarios that are utilized in the model. We then explain our simulation design which uses three management scenarios, three elevational groupings, and four climate scenarios on stands located on the Coconino and Kaibab National Forests. The simulations produce metrics which estimate future stand conditions, including total, living, and dead carbon stocks. These metrics are used to compare conditions across elevational groupings and management scenarios under the four climate scenarios.

\section{Experimental Section}

\subsection{Data and Study Area}

Data for our study were provided by the US Forest Service Four Forest Restoration Initiative (4FRI) team and comprised of annual forest inventories of ponderosa pine stands on the Coconino and Kaibab National Forests in Northern Arizona (Figure 1). The 4FRI is part of the US Forest Service's Collaborative Forest Landscape Restoration Program [44] and proposes to treat approximately 121,000 hectares in Arizona over 10 years. The closest weather station to our study site (2133 m elevation) recorded an average MAT of $8.1^{\circ} \mathrm{C}$ and $461.9 \mathrm{~mm}$ MAP for the 1979-2009 climate window [45]. Stands were delineated by the US Forest Service 4FRI team based on similar forest structural characteristics such as estimated age, height, and structure. Plots were randomly located within each stand and standard forest inventory variables were measured. The number of inventoried plots within each stand was proportional to the size of the stand. A total of 560 plots were located on 90 stands which comprised of approximately 2112 non-contiguous hectares. Current stand conditions are listed in Table 1.

Figure 1. Study area, Coconino County, Northern Arizona, United States. Stands (red) are distributed across the lower-Kaibab and upper-Coconino National Forests.

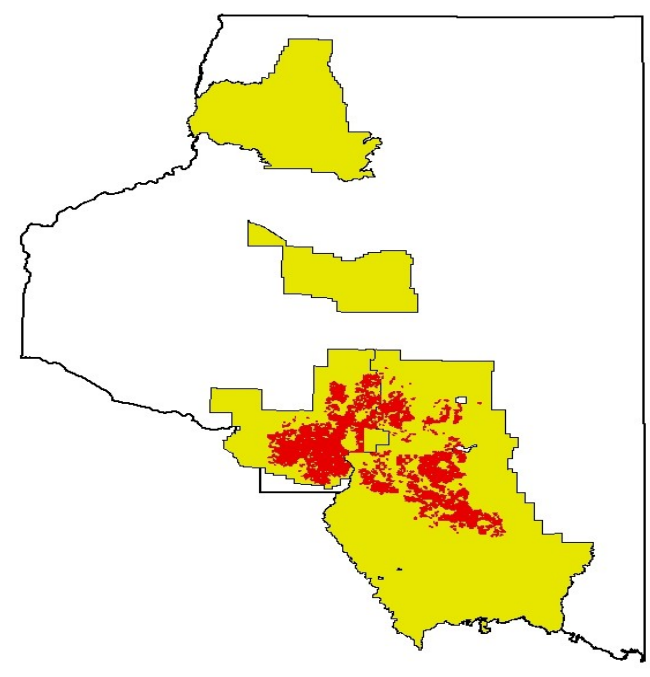

Legend

Study Stands

Kaibab and Coconino National Forests

Coconino County

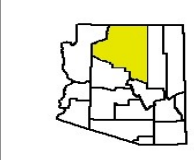


Table 1. Current stand conditions averaged from 30 stands per elevation group.

\begin{tabular}{ccccccccc}
\hline Elevation & TPH $^{\mathbf{1}}$ & BA $^{\mathbf{2}}$ & SDI $^{3}$ & QMD $^{4}$ & Can. Ht $^{5}$ & TI $^{\mathbf{6}}$ & Live C $^{7}$ & Dead C $^{8}$ \\
\hline Low 1950-2194 m & 510 & 36.7 & 366 & 14.0 & 3.5 & 57.5 & 91.0 & 12.6 \\
Mid 2194-2499 m & 338 & 28.0 & 259 & 19.1 & 4.7 & 135.8 & 68.8 & 10.1 \\
High 2499-2682 m & 213 & 42.5 & 363 & 21.3 & 4.4 & 58.6 & 105.8 & 15.0 \\
All Stands 1950-2682 m & 354 & 35.8 & 329 & 18.0 & 4.2 & 84.0 & 88.5 & 12.6 \\
\hline
\end{tabular}

${ }^{1}$ trees-per-hectare; ${ }^{2}$ basal area $\left(\mathrm{m}^{2} / \mathrm{ha}\right) ;{ }^{3}$ stand density index; ${ }^{4}$ quadratic mean diameter $(\mathrm{cm}) ;{ }^{5}$ canopy base height $(\mathrm{m}) ;{ }^{6}$ torching index $(\mathrm{km} / \mathrm{hr})[46,47] ;{ }^{7}$ carbon in living biomass (tons/ha); ${ }^{8}$ carbon in dead biomass (tons/ha).

\subsection{Representative Concentration Pathways}

To address uncertainty in the future emission of greenhouse gases (GHG), the Intergovernmental Panel on Climate Change (IPCC) has developed a variety of scenarios which describe a range of future GHG emission trajectories [23]. Prior to the IPCC's fifth Assessment Report (AR5), the IPCC had relied on different "storylines" to project societal parameters which are considered to be important drivers of climate change such as population growth, economic development, reliance on fossil fuels, and the rate at which technological innovation progresses [24]. The AOGCMs, which model climate through interactions between the ocean and atmosphere, would then use these storylines to project future climate conditions (i.e., GHG emissions, land-use change, and sea-level rise) and ultimately estimate the average global increase in temperature. These models have estimated that a doubling of the pre-industrial concentration of $\mathrm{CO}_{2}$ in the atmosphere (i.e., $280 \mathrm{ppm}$ to $560 \mathrm{ppm}$ ) would result in an average global temperature increase of $2{ }^{\circ} \mathrm{C}$ to $4{ }^{\circ} \mathrm{C}$ Celsius by the end of the century [23,24].

In the upcoming AR5, the IPCC adopts scenarios developed by the scientific community to model and assess future climate change [47]. The new generation of climate models creates a set of fixed anthropogenic and natural perturbations in earth's climate, represented by increases in radiative forcing by the end of the century, as measured in Watts per square meter $\left(\mathrm{W} / \mathrm{m}^{2}\right)$. This differs from the prior modeling approach in which the change in mean global temperature is estimated as a consequence of each storyline. The new scenarios are called Representative Concentration Pathways (RCPs) and simulate four scenarios in which the total radiative forcing increases by $2.6,4.5,6.0$, or $8.5 \mathrm{~W} / \mathrm{m}^{2}$ by the year 2100 [47]. Out of the four scenarios, we chose to simulate the RCP 4.5, 6.0, and 8.5 climate change scenarios in this study.

\subsection{Climate Extension to the Forest Vegetation Simulator}

We used the Central Rockies Variant of the Climate-FVS to predict stand conditions in Northern Arizona ponderosa pine forests under three RCP scenarios and a "no-climate-change" scenario. Our simulation period begins in 2010 and ends in 2110. Climate-FVS allows users to choose between various GCM projections of climate scenarios. For this study, an ensemble of 17 GCMs projecting the 4.5, 6.0, and 8.5 RCP scenarios was used to model future climate in Northern Arizona [48]. Climate-FVS is an extension to the base FVS model, which is a deterministic, individual-tree growth 
model [49]. FVS is a semi-distant-independent growth model, meaning that tree growth-and-mortality rates are adjusted based on density, and thus competition, within the stand. Climate-FVS modifies the species-specific tree-growth rates, site-index, and mortality rates of the base FVS model with the use of "species viability scores" [43]. For instance, if climate is projected to become more arid and less suitable for a particular species, the species viability score will decrease and Climate-FVS may implement, in some combination, decreasing growth rates, decreasing site index, and/or increasing mortality rates. Species viability scores are generated from the output of several successive models outside of the FVS model. The first model creates a "climate-surface" for a given location using a thin-plate-spline model [17]. The spline model inputs latitude, longitude, and elevation to interpolate climate variables from the nearest weather stations [17]. Future climate is then projected by downscaling GCM scenarios, i.e., RCPs, and a new climate surface is created by adding expected changes in climate variables to the prior vector of climate variables $[48,50]$. Once the present and future climate surfaces are developed, a Random Forest algorithm [51,52] predicts the presence or absence of a species at a location for a particular time and climate [43]. The output of the Random Forest algorithm is a proportion of bootstrapped "votes" in favor of a particular species occurring at a location under a certain climate $[43,48]$. Crookston et al. (2010) interpret these proportions as species viability scores, that is, "the likelihood (proportion of total votes cast) that the climate at a location would be suitable for a species" [43].

\subsection{Carbon Sub-Model of the Fire and Fuels Extension to the Forest Vegetation Simulator}

We simulated stand carbon dynamics in conjunction with the Climate-FVS using the Carbon Sub-model in the Fire and Fuels Extension (FFE) to the Forest Vegetation Simulator (FVS) [53]. The Carbon Sub-model estimates stand carbon by simply multiplying the dry weight of living and dead biomass by 0.5 and multiplying estimates of litter and duff weight by 0.37 [53]. The Sub-model reports the carbon stored (tonnes per hectare) in the total aboveground live biomass, belowground live biomass, belowground dead biomass, standing dead biomass, forest down dead wood, forest floor biomass, herbs and shrubs, and merchantable aboveground live biomass. Each of these categories is described in detail in Rebain (2013) [53]. For simplification in reporting, we group carbon into two categories, living carbon or dead carbon. The living carbon grouping is a summation of the estimated carbon reported in the aboveground live, belowground live, and herbs and shrubs categories from the Sub-model. The dead carbon grouping consists of the belowground dead, standing dead, forest down dead wood, and forest floor values reported by the Sub-model. We do not include any analysis of carbon stored in long-lived wood products from tree removals.

\subsection{Elevation}

Elevation is a major determinant of stand composition and stand structure in SW US ponderosa pine forests $[2,13,14,25]$. Higher MAT and lower MAP in lower elevation stands tends to promote shorter fire-return intervals, leading to more open, park-like settings in ponderosa pine stands $[8,54,55]$. Whereas lower MAT and higher MAP in higher elevation stands can improve the productivity of a site, resulting in a denser stand with greater species diversity. Elevation for each stand was determined by overlaying stand polygons on a US Geologic Survey digital elevation model (DEM) layer in 
ArcMap 10.1 GIS software and calculating the median elevation value within each polygon. We used this method because elevation was only recorded on $18 \%$ of the USFS inventoried stands. However, when elevation was recorded within the stand, the maximum deviation between our calculation and the measured elevation was 36.6 meters (1.5 meters average deviation), providing assurance that our methodology for calculating stand elevation was sound.

To describe changing conditions at various elevations, we stratified stands by lower, mid, and higher elevation so that each elevational group contained 30 stands. Our results always present the averaged output of each 30-stand elevational grouping, i.e., one average for each group. The lower elevation grouping is defined by stands located between elevations of $1950 \mathrm{~m}$ and $2194 \mathrm{~m}$. The middle elevation grouping is defined by stands located between $2194 \mathrm{~m}$ and $2499 \mathrm{~m}$, and the higher elevation group included stands falling in the $2499 \mathrm{~m}$ to $2682 \mathrm{~m}$ range. We chose these groupings based on an examination of the literature and a preliminary examination of the data [13,14,25]. A one-way ANOVA implemented in $\mathrm{R}$ statistical software found statistically significant differences for MAP $(p<0.001)$ and MAT $(p<0.001)$ between elevational groupings for the period between 1990 and 2010. Initial conditions among these groupings are described in Table 1.

\subsection{Management Scenarios}

Large uncertainty remains as to whether thinning treatments can effectively mitigate carbon losses due to climate change. Therefore, in addition to projecting changing stand conditions across an elevational gradient, we also applied two management scenarios in conjunction with a no-management scenario to simulate various management prescriptions over the 100 year time-span. We use the FFE-FVS carbon model to estimate stand carbon dynamics in light of management and climate change. Management scenarios were implemented in Climate-FVS and were designed to mimic common and proposed management practices in the dense, over-stocked ponderosa pine forests of Northern Arizona. The management scenarios selected for this study were influenced by prescriptions developed by the US Forest Service's 4FRI team and a review of the literature [33,56-61]. However, we note that the silvicultural prescriptions proposed by the 4FRI team are much more complex than our design and are tailored toward multi-objective management [56,57]. A review of the literature also lent support for our management scenarios [31-33,59-61].

The first management scenario is a "no-management" scenario that is used as a baseline for evaluating the effectiveness of management. The second management scenario is referred to as a moderate-management scenario that always implements a mechanical thinning proceeded by a controlled burn. The controlled burn is set to occur in the early spring, with wind-speeds less than $13 \mathrm{~km} /$ hour. This treatment is conditionally scheduled to occur when, and if, the stand basal area (BA) becomes greater than $37 \mathrm{~m}^{2} /$ ha. Treatment consists of a thin-from-below to a target basal area of $28 \mathrm{~m}^{2} /$ ha, which is then followed by a controlled burn. The moderate scenario places a 41-centimeter diameter limit on trees available for removal, which reflects a policy proposed by the 4FRI stakeholders group [58]. We acknowledge that a target residual BA of $28 \mathrm{~m}^{2} /$ ha is not optimal for fire-hazard reduction. However, we wanted to maintain the 41-centimeter diameter limit in order to assess the potential impacts of that provision. Climate-FVS evaluates whether BA is greater than 37 $\mathrm{m}^{2} /$ ha every 10 years beginning in the first period, i.e., 2010. Once the moderate scenario treatment has 
been initialized, we limit Climate-FVS from performing another treatment for at least 20 years, with a maximum of five treatments over the 100 year time-span. Table 2 lists the provisions of the moderate scenario. The third management scenario is referred to as the intensive-management scenario. Like the moderate scenario, a treatment in the intensive scenario always implements a mechanical thinning followed by a controlled burn. This scenario initializes when stand BA becomes greater than $28 \mathrm{~m}^{2} / \mathrm{ha}$ and is permitted to occur every 10 years cycle. Treatment consists of a thin-from-below to a residual target $\mathrm{BA}$ of $18 \mathrm{~m}^{2} / \mathrm{h}$, which is $9 \mathrm{~m}^{2} /$ ha more BA removed in the thinning compared to the moderate scenario. Studies suggest that pre-settlement conditions in our study area contained approximately 5 to $21 \mathrm{~m}^{2} /$ ha BA before extensive fire-exclusion policies were implemented [33,57] The intensive scenario eases the constraints of the diameter limit on removal trees to 61 centimeters.

The Central Rockies Variant of the Climate-FVS does not contain a full regeneration model and requires the user to manually designate the frequency and establishment of regeneration [49]. We turned to the literature to determine regeneration rates of ponderosa pine for the region. Ponderosa pine has periodic seed dispersal, and in a seed bearing year over 1012 seeds/ha may be dispersed [62]. Germination and survival of these seeds depends on the availability of a suitable seedbed. One study estimated that up to 100 trees/ha could survive into the over-story after a treatment using mechanical thinning followed by prescribed burn [62]. We set regeneration to 65 stems/ha whenever stocking dips below 40 percent. Due to the difficulty of modeling the highly variable seed dispersal of ponderosa pine in FVS, we decided that 65 stems/ha was a conservative estimate of regeneration. We did not consider the effect of species migration and only simulated regeneration of species present on the stand.

Table 2. Summary of Climate-FVS (Forest Vegetation Simulator) parameters for management scenarios over the 100 year simulation period.

\begin{tabular}{ccccc}
\hline $\begin{array}{c}\text { Management } \\
\text { Scenario }\end{array}$ & Initializing BA $\left(\mathbf{m}^{\mathbf{2}} / \mathbf{h a}\right)$ & $\begin{array}{c}\text { Residual Target BA } \\
\left(\mathbf{m}^{\mathbf{2}} / \mathbf{h a}\right)\end{array}$ & $\begin{array}{c}\text { Diameter Limit } \\
(\text { Removal } \mathbf{~ c m})\end{array}$ & $\begin{array}{c}\text { Treatment } \\
\text { Frequency }\end{array}$ \\
\hline Moderate & 37 & 28 & $41 \mathrm{~cm}$ & 20 years \\
Intensive & 28 & 18 & $61 \mathrm{~cm}$ & 10 years \\
\hline
\end{tabular}

\section{Results and Discussion}

\subsection{Baseline Conditions}

We used a set of baseline stand conditions to simulate the relative changes in stand structure between climate, management, and elevational differences over time. The baseline conditions simulated stand dynamics by elevational grouping over a 100 year time-frame without any management and under the assumption that climate will not change [63]. Table 3 lists stand conditions, averaged by elevational grouping (low, mid, high), including trees-per-hectare (TPH), basal area (BA), and quadratic mean diameter (QMD). 
Table 3. Projected stand conditions under no climate change and no management.

\begin{tabular}{cccccccccc}
\hline & \multicolumn{3}{c}{ Trees Per Hectare } & \multicolumn{3}{c}{ Basal Area $\left(\mathbf{m}^{\mathbf{2}} / \mathbf{h a}\right)$} & \multicolumn{3}{c}{ Quadratic Mean Diameter $(\mathbf{c m})$} \\
\hline $\begin{array}{c}\text { Elevation } \\
\text { Year }\end{array}$ & Low & Mid & High & Low & Mid & High & Low & Mid & High \\
2010 & 510 & 338 & 212 & 37 & 28 & 42 & 14 & 19 & 21 \\
2020 & 478 & 333 & 214 & 40 & 31 & 45 & 15 & 20 & 22 \\
2030 & 462 & 324 & 224 & 43 & 35 & 48 & 15 & 22 & 22 \\
2040 & 425 & 287 & 233 & 45 & 37 & 50 & 16 & 24 & 23 \\
2050 & 393 & 255 & 227 & 47 & 39 & 52 & 17 & 25 & 24 \\
2060 & 374 & 229 & 227 & 48 & 41 & 54 & 18 & 27 & 25 \\
2070 & 347 & 202 & 224 & 50 & 42 & 55 & 19 & 29 & 25 \\
2080 & 333 & 177 & 207 & 51 & 43 & 56 & 19 & 30 & 26 \\
2090 & 313 & 156 & 194 & 52 & 43 & 57 & 20 & 32 & 27 \\
2100 & 296 & 139 & 177 & 53 & 43 & 58 & 21 & 34 & 29 \\
2110 & 284 & 125 & 162 & 53 & 43 & 59 & 22 & 36 & 30 \\
\hline
\end{tabular}

We compared our data with findings from Fulé et al. 2007, who used tree-ring analysis to reconstruct historic conditions in northern Arizona ponderosa pine stands (2134 $\mathrm{m}$ elevation) [59]. That study found pre-settlement BA to range between 17 and $27 \mathrm{~m}^{2} /$ ha $(95 \%$ confidence interval), TPH to range between 51 and 79 (95\% confidence interval), and QMD to range between 36 and 47 centimeters (95\% confidence interval) [59]. Our results indicate that the average lower-elevation stand contains many small-diameter trees at the beginning of the simulation period and develops dense, dog-hair-thicket type conditions by the end of the century. The average stand TPH decreases while QMD increases to $22 \mathrm{~cm}$ over the century, exhibiting competition-driven mortality. Projected conditions in the average lower-elevation stand characterize many of the current ponderosa pine forests of the SW US that are at high-risk of catastrophic wildfire [31,59]. The average stand in the mid-elevational grouping maintains the lowest BA relative to the other stands over the time-frame, yet is still initially over-stocked. By the end of the simulation period, mid-elevation stand conditions are still likely to be over-stocked and outside the historic, i.e., pre-settlement, range of variability [59]. Higher-elevation ponderosa pine stands are excessively stocked with BA at $42 \mathrm{~m}^{2} / \mathrm{ha}$ in the beginning of the simulation period. These stands reach near-saturation levels, i.e., maximum BA values, by 2110 . Overall, without management or climate change, BA across all elevational groups becomes exceedingly high, further aggravating the current fuel loadings in these stands.

\subsection{Stand Dynamics in a Changing Climate without Management}

\subsubsection{Effects of Climate Change in Lower Elevation Stands}

Lower elevation stands are likely to experience the most drastic changes in terms of permanent loss of ponderosa pine forest cover under the RCP 6.0 and RCP 8.5 climate change scenarios (Figure 2). We calculated net growth $\left(\mathrm{m}^{3} / \mathrm{ha}\right)$ defined as expected stand growth minus mortality. In the RCP 8.5 scenario stands experience almost complete loss of forest cover by 2090, as indicated by steep declines in BA that begin in 2050 and bottom-out by the end of the century. By late century, zero net growth occurs simultaneously with BA reaching a minimum, suggesting stands have total forest cover loss. In 
lower elevation stands, average growth is larger than average mortality until mid-century for the RCP 4.5 and RCP 6.0 scenarios. These more moderate climate change scenarios prolong any climate-induced mortality until approximately the third-quarter of the century. Basal area therefore remains at extremely high levels before experiencing almost complete decimation. This finding suggests that the fire-hazard within these stands will only increase in the near term, as a more arid climate will only promote drier fuel conditions and perhaps increased frequency and severity of wildfires (Figure 2) [4,6,9].

Figure 2. Conditions in stands projected for three elevational groupings (lower, medium, and higher elevation) under three warming climate scenarios, RCP 4.5 (Blue), RCP 6.0 (Red), and RCP 8.5 (Black). Projections do not simulate any forest management. Mean annual temperature (MAT) and mean annual precipitation (MAP) data were only available for 1990 to 2090 . Basal area is measured in $\mathrm{m}^{2} /$ ha. Net growth is calculated as average stand growth $\left(\mathrm{m}^{3} / \mathrm{ha}\right)$ minus average stand mortality $\left(\mathrm{m}^{3} / \mathrm{ha}\right)$.
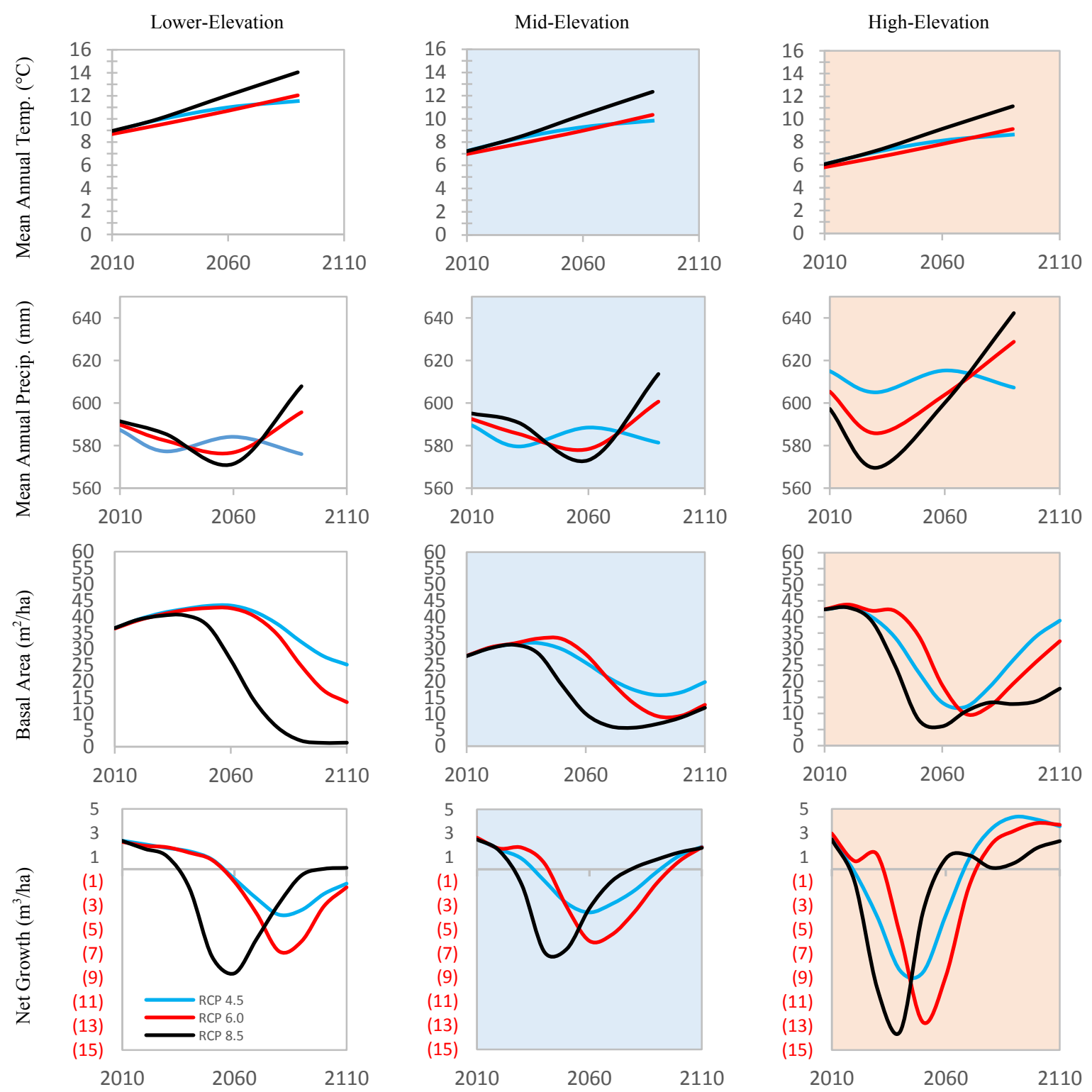


\subsubsection{Effects of Climate Change on Mid-Elevation Stands}

Mid-elevation stands respond similarly to the lower-elevation stands for most climate change scenarios (middle column Figure 2). The most pronounced difference between elevations is seen in the RCP 8.5 scenario. Under this scenario, stand mortality peaks around year 2070, but rather than maintaining barren conditions like the lower-elevation stands, BA and growth begin to recover in the mid-elevation stands. Stands exhibit high mortality (negative net growth) under all climate scenarios, yet seem to rebound sooner in the RCP 8.5 scenario versus the other two more modest climate scenarios. One possible explanation for this projection is that the higher levels of mortality earlier in the simulation period may lead to reduced over-story competition and quicker establishment of regeneration. An examination of FVS output seems to support this hypothesis, as crown competition factor [64] drops quicker and regeneration initiates earlier for stands in the RCP 8.5 scenario. Density in these stands is not as high as the lower-elevation stands and poses a relatively lower risk of catastrophic wildfire.

\subsubsection{Effects of Climate Change on High-Elevation Stands}

High-elevation stands are projected to experience the most mortality out of the three elevations (right-most column Figure 2); however, they also exhibit the largest levels of resilience to climate change compared with the other elevations, over the long run. These stands have the highest initial BAs, and these levels persist until 2030 or 2040 depending on the climate scenario. The RCP 8.5 scenario projects net annual mortality rates over $11 \mathrm{~m}^{3} /$ ha by 2030 , and even the most modest climate scenario, RCP 4.5, projects net annual mortality to peak at approximately $9.1 \mathrm{~m}^{3} /$ ha by 2045 . However, higher-elevation stands appear to exhibit greater resilience to climate change, over the long run, than the other elevations. All scenarios reach positive net growth by approximately 2075, which largely coincides with projected increases in MAP. In all scenarios, MAP has initial decreases but eventually increases to levels higher than the initial starting MAP. While GCMs are less confident in projections of MAP in the SW US [4,7,24], increasing MAP seems to influence stand resilience (Figure 2).

The higher-elevation ponderosa pine stands contain pockets of aspen (Populus tremuloides) and mixed conifers. These components had the most rapid declines in species viability scores, as output by the Climate-FVS, which projected complete mortality of these species (data not shown). Decreasing ponderosa pine viability scores, in conjunction with the declines in other species scores, explains the immense mortality at the beginning of the projection period. The projected mortality may also be a function of declining MAP in higher-elevation stands at the beginning of the project time frame. Precipitation initially displays sudden decreases in the higher-elevation stands, unlike the decreases projected for the low and mid elevation stands which follow a gradually decreasing trend. The montane species present in many of our high-elevation stands are ill-adapted to drought and have been observed to experience increased rates of mortality in the SW US due to a more arid climate [1-3].

Overall, ponderosa pine stands are projected to experience high rates of mortality, regardless of climate change scenario or elevational grouping. Lower-elevation stands are projected to experience the most devastating and permanent losses, while both mid and high elevation stands experience large initial losses followed by a period of recovery. It is important to note that these climate change 
scenarios do not take into account increasing vulnerability, and likely occurrence, of stands to high severity wildfires. Initial stand conditions at all elevations are overstocked and at risk of stand-replacing wildfire [31-33,59]. Increased mortality will only exacerbate fuel loadings and the likelihood of crown fires. Therefore, some form of management should take place on these stands that aims to capture the seemingly imminent mortality. Management may have the dual benefit of decreasing fire-risk and increasing resilience to climate change.

\subsection{Management, Elevation, and Climate Change}

Management was simulated at three different intensities across elevational groupings and under the various climate scenarios. Figure 3 provides an example of how management affects stand BA and net growth for the RCP 6.0 climate change scenario. We chose to present the management impacts under this scenario for sake of brevity, as management effects trended similarly across the three RCP climate change scenarios. A more comprehensive comparison of management effects across all climate change scenarios and elevational groups is discussed in the subsequent section on carbon storage. Out of the three management scenarios, the intensive management scenario maintained a relatively consistent level of BA (i.e., between 9 and $38 \mathrm{~m}^{2} / \mathrm{ha}$ ) and net growth (i.e., between -7.0 and $2.8 \mathrm{~m}^{3} / \mathrm{ha}$ ) over all elevations as compared to the other management scenarios (Figure 3). The intensive scenario was most successful at accomplishing its objectives of decreasing fire-risk and increasing resilience to climate change in the lower-elevation stands, where BA was always below $28 \mathrm{~m}^{2} /$ ha. While the target residual BA was set to $18 \mathrm{~m}^{2} /$ ha, the 61-centimeter diameter limit on tree-removal made this target difficult to accomplish for all elevational groupings. The intensive scenario demonstrated highest variability in both BA and net growth in the high-elevation stands, yet was still more effective than the moderate and no treatment scenarios at reducing fire-risk and increasing resilience to climate change.

Under the intensive management scenario, increases in BA and net growth at the end of the simulation resulted in a very different stand structure than at the beginning of the simulation period. For instance, in low-elevation stands, average TPH and QMD in 2110 are projected at approximately 405 and $8 \mathrm{~cm}$, respectively, compared to $214 \mathrm{TPH}$ and $30 \mathrm{~cm}$ QMD at the beginning of the simulation period (data not shown). In mid-elevation stands, average TPH and QMD in 2110 are approximately 384 and $10 \mathrm{~cm}$, respectively, versus $289 \mathrm{TPH}$ and $23 \mathrm{~cm}$ QMD in 2010 (data not shown). In high-elevation stands, average TPH and QMD in 2110 are 121 and $15 \mathrm{~cm}$, respectively, as compared to $134 \mathrm{TPH}$ and $28 \mathrm{~cm}$ QMD in 2010 (data not-shown). These results suggest that despite increases in BA by late 21 st Century in the mid and high elevation stands, climate change will result in large decreases in stand BA and forest cover. Additionally, the structure of all stands shifts to few small diameter trees by the end of the simulation period. Therefore, while the intensive management can maintain ponderosa pine forest cover, the RCP 6.0 climate change scenario appears to constrain the growth and overall vigor of these forests. 
Figure 3. Effect of management on stand resilience for low, mid, and higher elevation ponderosa pine groups under the RCP 6.0 climate change scenario. Management scenarios include a no management (purple), moderate-intensity management (brown), and intensive management (green) described in Section 2.6. Left column compares BA and right column compares net growth for different management intensities. Upper row presents lower-elevation stands, middle row presents mid-elevation stands, and bottom row presents higher-elevation stands.
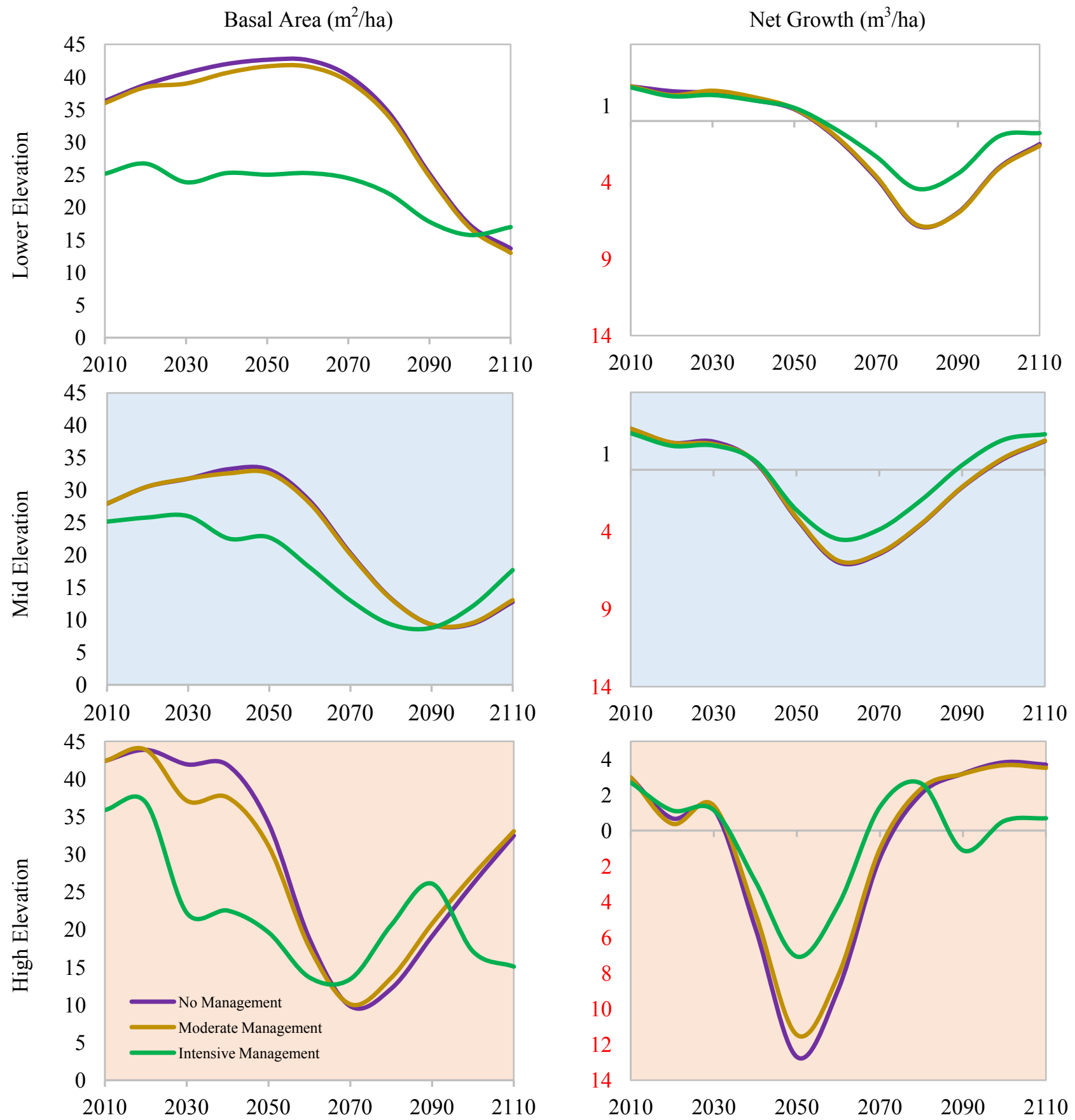

Management was ineffective under the moderate-intensity scenario at all elevations. Differences were almost indiscernible between stands receiving the moderate-intensity treatment and stands with no treatment. A consistent problem encountered when running the moderate-intensity management 
simulations in Climate-FVS was the inability to remove enough volume to reach the target residual BA. The 41-centimeter diameter limit on tree removal prevented sufficient removal of volume to reach the target residual BA of $28 \mathrm{~m}^{2} /$ ha. Failure to decrease BA in the moderate management scenario resulted in high stand density until about mid-century where climate-induced mortality seemed to cause dramatic declines in forest cover. The US Forest Services' landscape-scale 4FRI treatments have decided to implement a 46-centimeter diameter limit as opposed to the 41-centimeter limit suggested by the 4FRI stakeholder's group [56-58]. This study did not test the effectiveness of a 46-centimeter diameter limit. Overall, our results suggest that the intensive treatment scenario was most effective at mitigating climate-induced mortality. This treatment schedule called for thinning stands to a residual BA of $18 \mathrm{~m}^{2} /$ ha whenever BA was greater than $28 \mathrm{~m}^{2} /$ ha, with removal limited to trees 61 centimeters in diameter or less, followed by a prescribed fire up to every 10 years.

\subsection{Carbon Storage, Management, and Climate Change}

Carbon stores on our study area were particularly vulnerable to catastrophic losses under almost all climate change scenarios and all elevational groupings when compared to the no climate change scenario (Figure 4). The RCP 8.5 climate change scenario rendered any management scenario, including the no management scenario, ineffective at retaining carbon in living biomass for all elevational groupings. We distinguish between living carbon, which has the ability to sequester carbon from the atmosphere, and dead carbon, which is more of a liability in these fire-prone forests.

The left-most column of Figure 4 displays carbon stocks in lower elevation stands and the effects of management (rows) and climate change scenarios (groups of stacked bars within each cell) on these stocks over time. Average stand carbon in the no-management, no-climate-change scenario reaches extraordinary levels by mid-century, i.e., over 135 tons/ha. Such high levels of carbon are unlikely to remain in these lower-elevation stands, as wildfire would typically release at least $20 \%$ of stand carbon per event [34-39,65]. Wildfire exclusion in these low-elevation stands results in carbon increasing to over 179 tons/ha by the beginning of the 22nd century, assuming climate remains constant. However, even in the most modest climate change scenario, over $50 \%$ of stand carbon is projected to become dead carbon (78 tons/ha dead versus 74 tons/ha living) by the end of the simulation period. The percentage of dead carbon in the low-elevation stands reaches $90 \%$ (74 tons/ha dead versus 9 tons/ha live) by 2110 for the RCP 8.5 scenario.

Carbon storage in mid-elevation stands is shown in the middle column of Figure 4 . The ratio of living to dead carbon closely resembles that of the lower-elevation stands, with the exception of increases in living carbon towards the end of the simulation period in the climate change scenarios. This trend of rebounding living carbon is consistent with the prior analysis in Section 3.3 where BA and net growth both begin to increase towards the latter half of the century. Total carbon stocks are virtually identical between the moderate and no management groups for all climate scenarios due to the 41-centimeter diameter limit on tree-removals. 
Figure 4. Average estimated carbon stocks in ponderosa pine stands. Each cell contains total living and dead carbon (tons/hectare) projected over 100 years (2010 to 2110) under four climate scenarios. Rows show average stand carbon grouped by three management scenarios. Columns display average carbon stocks in stands grouped by elevation.
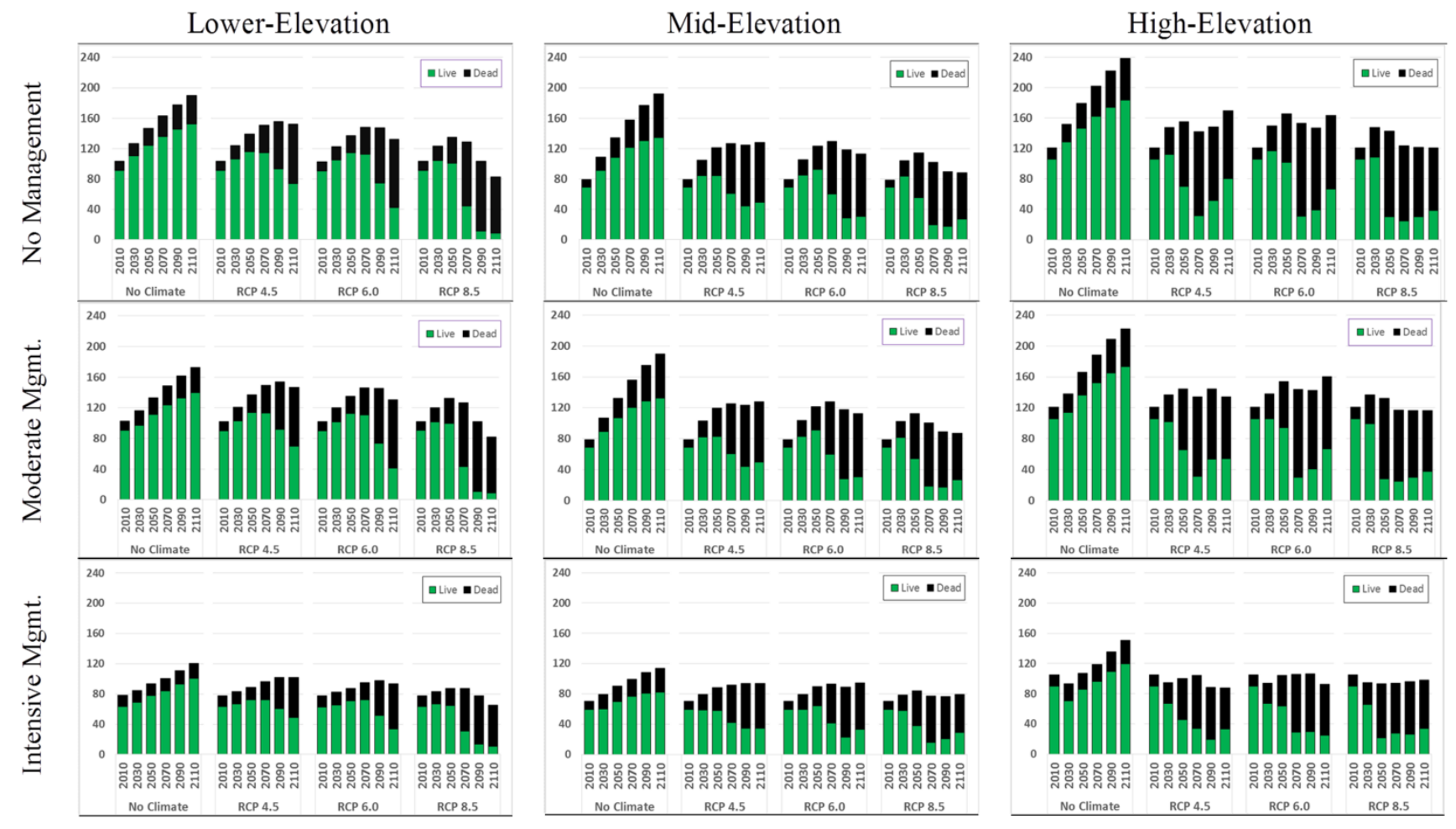

Carbon storage in the high-elevation stands is consistently greater than all other elevational gradients when compared within the same climate scenario (Figure 4 right-most column). However, living carbon is projected to experience the greatest losses due to climate change in high-elevation stands compared to the other elevational groups. For instance, average living carbon is 184 tons/ha by the end of the simulation period for the no-climate-change scenario versus only 38 tons/ac living carbon in 2110 for the RCP 8.5 scenario.

Management has little effect on maintaining living carbon for all climate change scenarios. As expected, carbon stocks are lower for the two managed scenarios when compared to the no-management scenario. However, in the fire-excluded ponderosa pine forests of the SW US, some have argued that these overstocked, carbon-rich forests are beyond the stand's carbon-carrying-capacity and in need of carbon removal [35-40,66,67]. Carbon carrying capacity is defined as "the mass of carbon able to be stored in a forest ecosystem under prevailing environmental conditions and natural disturbance regimes, but excluding anthropogenic disturbance" [67]. The fire-exclusion policies of the 20th century are an anthropogenic disturbance that has altered natural disturbance regimes in the southwestern ponderosa pine ecosystem [31,32]. While we make no attempt to quantitatively define the carbon carrying capacity for this study area, we broadly define it as the maximum carbon storage obtainable while maintaining an acceptable level of hazardous fire risk. Therefore, the intensive management scenario appears to be the most effective scenario for bringing conditions closer to the theoretical carbon carrying capacity. This study does not consider the effect of long-term carbon storage in wood products from thinning treatments, which would lend further support 
for the intensive management scenario. In conclusion, climate change has a far greater effect on carbon stocks than does management or elevational grouping.

\subsection{Broader Implications of Results}

This study illustrates the utility of incorporating the effects of climate change into management decisions. Climate-FVS may serve as an important tool available to forest managers for evaluating the effectiveness of proposed treatments. Decisions about the timing, frequency and magnitude of treatments should now be evaluated in light of the range of climate change intensities. For instance, we found that climate-induced mortality is lowest when treatment is frequent and permitted to remove sufficient volume to reduce BA below $28 \mathrm{~m}^{2} /$ ha (Figure 3). However, under the RCP 8.5 climate change scenario, severe mortality of ponderosa pine appears imminent regardless of treatment.

Moreover, our simulation results uncover the consequences of inaction, especially under a drier climate in the future. For example, if management does not occur, or is implemented at an inadequate intensity, fuels (as represented by dead carbon in Figure 4) will accumulate to potentially unprecedented high levels under the RCP 4.5, RCP 6.0, and RCP 8.5 scenarios. If forest managers are faced with these climatic conditions in the future, they will have to re-evaluate their management objectives and conduct earlier, more frequent and more intensive treatments to avoid increased fire risk and potentially catastrophic wildfires. Under the selected climate scenarios, inaction by forest managers in the near term will likely result in a missed opportunity to perform treatments that could prevent devastating losses of forest cover.

\subsection{Study Limitations}

It should first be noted when interpreting the results of this study, that the FVS is a deterministic model which does not output statistical validation data such as standard errors. However, the FVS has been a widely used growth-model within the scientific and management communities for over 30 years, and has been continuously improved since its inception. Therefore, the results should be interpreted with caution, noting that the projections lack estimates of error and are likely outcomes of future stand conditions.

Secondly, we do not make any attempt at explicitly simulating the effects of wildfire or changes in wildfire behavior and frequency, nor do we simulate pathogen and insect outbreaks. The Climate-FVS does not make any distinction between the causal agents of mortality within a stand. Instead, it relies on the species viability scores, which are interpreted as probabilities that a certain species will occur at a given location under a particular climate, to modify the base FVS rate of mortality, the site index, and growth rates. Thus, mortality occurring within the Climate-FVS may be the result of increased wildfire frequency and intensity, or pathogen and insect outbreaks, yet the model makes no attempt to distinguish causes of mortality. The FVS does have available extensions for modeling insect outbreaks, pathogens, and fire behavior and effects. However, we focus solely on how climate change may affect stand development. Further research is needed that explores how these other agents of mortality will affect stand dynamics under climate change.

In addition, Climate-FVS does not incorporate the effects of increased levels of plant-available $\mathrm{CO}_{2}$ on tree growth. Higher concentrations of atmospheric $\mathrm{CO}_{2}$ are likely to increase the water-use 
efficiency and growth rates of ponderosa pine during periods of drought [66]. However, a stronger evaporative demand due to increased temperatures may nullify any benefit of additional carbon fertilization $[4,67]$. Climate-FVS makes no attempt to simulate the effect of increased atmospheric $\mathrm{CO}_{2}$ concentrations on individual tree growth $[43,48]$. However, Crookston $(2013)$ tested the potential benefit of carbon fertilization by increasing species viability scores, i.e., representing increased growth and viability, and found that these modifications had little to no effect on stand biomass production [48]. Further research is needed to fully understand how carbon fertilization will affect overall ponderosa pine growth and survival in future climates, and our results should be interpreted with this limitation in mind.

\section{Conclusions}

This study simulated ponderosa pine stand development in Climate-FVS to evaluate the likely impacts of various climate change scenarios. The first objective of this study was to evaluate the effects of climate change across the elevational range of ponderosa pine forests. Stands were stratified in low, mid, and high-elevational groups in order to assess any potential differences in developmental dynamics under each climate scenario. Results show that ponderosa pine forests at all elevations are likely to experience high rates of mortality in even the most modest climate change scenario (RCP 4.5). Lower-elevation stands are likely to undergo the most devastating, and lasting, levels of mortality and loss of forest cover. The mid and high-elevation groupings also endure considerable mortality by mid-21st Century under all climate change scenarios. However, the mid and higher-elevation stands appear to initiate recovery by late 21 st Century.

Our second objective was to assess whether management could mitigate the negative effects of climate change on stand development and stand carbon stocks. Two management scenarios were scheduled and compared to a baseline "no-management" scenario. Results indicate that the intensive management scenarios was most effective at mitigating climate-driven mortality for the RCP 4.5 and RCP 6.0 climate scenarios in lower-elevation stands. Carbon stocks were consistently lower under the intensive management schedule compared to the no and moderate management scenarios. However, other research suggests that conditions in the carbon-rich unmanaged and moderately managed stands are unsustainable and prone to catastrophic losses from wildfire [34-40,68,69].

The implications of our findings suggests that many ponderosa pine forests in the SW US are likely to undergo drastic changes in stand structure due to climate-driven mortality. Current conditions in many of the ponderosa pine forests of the SW US are overstocked and at risk of catastrophic wildfire. Intensive management appears to have the dual benefit of reducing wildfire risk and promoting stand resilience to climate change. Management may mitigate some loss of forest cover at all elevations. However, management is only effective when implemented through intensive, more frequent treatments, while diameter limits on tree removal appear to be a limiting factor on treatment effectiveness. One of the primary objectives of forest management is to promote forest health and to capture and utilize imminent mortality in forest products [70]. As widespread mortality events increase in frequency and severity throughout the SW US as a result of climate change, resource managers must continue to emphasize the importance of forest management as a tool for mitigating climate change induced mortality. 


\section{Acknowledgments}

This research was funded by a McIntire-Stennis Grant. The authors thank Neil McCusker and Mark Nigrelli of the US Forest Service 4FRI team for providing and navigating the data used in this study. The authors would also like to thank Andrew Sanchez-Meador for his advice on configuring regeneration within the FVS and his guidance on running Climate-FVS. We would also like to thank the two peer-reviewers and the editor for their helpful comments and suggestions for strengthening this manuscript.

\section{Author Contributions}

Both Benjamin Bagdon and Ching-Hsun Huang were responsible for the study design and development. Benjamin Bagdon, collected, prepared, and analyzed all data and ran all model simulations. Benjamin prepared and revised the manuscript. Dr. Ching-Hsun Huang contributed to the manuscript revisions.

\section{Conflicts of Interest}

The authors declare no conflict of interest.

\section{References and Notes}

1. Breshears, D.D. Regional vegetation die-off in response to global-change-type drought. Proc. Natl. Acad. Sci. 2005, 102, 15144-15148.

2. Kelly, A.E.; Goulden, M.L. Rapid shifts in plant distribution with recent climate change. Proc. Natl. Acad. Sci. 2008, 105, 11823-11826.

3. Rehfeldt, G.E.; Ferguson, D.E.; Crookston, N.L. Aspen, climate, and sudden decline in western USA. For. Ecol. Manag. 2009, 258, 2353-2364.

4. Williams, A.P.; Allen, C.D.; Macalady, A.K.; Griffin, D.; Woodhouse, C.A.; Meko, D.M.; Swetnam, T.W.; Rauscher, S.A.; Seager, R.; Grissino-Mayer, H.D.; et al. Temperature as a potent driver of regional forest drought stress and tree mortality. Nat. Clim. Chang. 2012, 3, 292-298.

5. Brusca, R.C.; Wiens, J.F.; Meyer, W.M.; Eble, J.; Franklin, K.; Overpeck, J.T.; Moore, W. Dramatic response to climate change in the Southwest: Robert Whittaker's 1963 Arizona Mountain plant transect revisited. Ecol. Evol. 2013, 3, 3307-3319.

6. Swetnam, T.W.; Betancourt, J.L. Mesoscale disturbance and ecological response to decadal climatic variability in the American Southwest. J. Clim. 1997, 11, 3128-3147.

7. Christensen, J.H.; Hewitson, B.; Busuioc, A.; Chen, A.; Gao, X.; Held, I.; Jones, R.; Kolli, R.K.; Kwon, W.T.; Laprise, R.; et al. Regional Climate Projections. In Climate Change 2007: The Physical Science Basis. Contribution of Working Group I to the Fourth Assessment Report of the Intergovernmental Panel on Climate Change; Solomon, S., Qin, D., Manning, M., Chen, Z., Marquis, M., Averyt, K.B., Tignor, M., Miller, H.L.; Eds.; Cambridge University Press: Cambridge, UK, 2007; pp. 847-940.

8. Grissino-Mayer, H.D.; Swetnam, T.W. Century-scale climate forcing of fire regimes in the American Southwest. Holocene 2000, 10, 213-229. 
9. Westerling, A.L.; Hidalgo, H.G.; Cayan, D.R.; Swetnam, T.W. Warming and earlier spring increase western US forest wildfire activity. Science 2006, 313, 940-943.

10. Bentz, B.J.; Régnière, J.; Fettig, C.J.; Hansen, E.M.; Hayes, J.L.; Hicke, J.A.; Kelsey, R.G.; Negron, J.F.; Seybold, S.J. Climate change and bark beetles of the western United States and Canada: direct and indirect effects. Biosci. 2010, 60, 602-613.

11. Van Mantgem, P.J.; Stephenson, N.L.; Byrne, J.C.; Daniels, L.D.; Franklin, J.F.; Fulé, P.Z.; Harmon, M.E.; Larson, A.J.; Smith, J.M.; Taylor, A.H.; Veblen, T.T. Widespread increase in tree mortality rates in the Western United States. Science 2009, 323, 521-524.

12. Breshears, D.D.; Allen, C.D. The importance of rapid, disturbance-induced losses in carbon management and sequestration. Glob. Ecol. Biogeog. 2002, 11, 1-5.

13. Schubert, G.H. Silviculture of Southwestern Ponderosa pine: The Status of our Knowledge; General Technical Report RMRS-GTR-123; U.S. Department of Agriculture, Forest Service, Rocky Mountain Research Station: Fort Collins, CO, USA, 1974; p. 7.

14. Merriam, C.H. Results of a Biological Survey on the San Francisco Mountain Region and Desert of the Little Colorado, Arizona; North. Am. Fauna No. 3; U.S. Department of Agriculture: Washington, DC, USA, 1890; pp. 7-13.

15. Ogle, K.; Whitham, T.G.; Cobb, N.S. Tree-ring variation in pinyon pine predicts likelihood of death following severe drought. Ecology 2000, 81, 3237-3243.

16. Nevo, E. Evolution of genome-phenome diversity under environmental stress. Proc. Natl. Acad. Sci. 2001, 98, 6233-6240.

17. Rehfeldt, G.E. A Spline Model of Climate for the Western United States; General Technical Report RMRS-GTR-165; Department of Agriculture, Forest Service, Rocky Mountain Research Station: Fort Collins, CO, USA, 2006; pp. 1-20.

18. Gray, S.T.; Betancourt, J.L.; Jackson, S.T.; Eddy, R.G. Role of multidecadal climate variability in a range extension of pinyon pine. Ecology 2006, 87, 1124-1130.

19. McDowell, N.; Pockman, W.T.; Allen, C.D.; Breshears, D.D.; Cobb, N.; Kolb, T.; Plaut, J.; Sperry, J.; West, A.; Williams, D.G.; Yepez, E.A. Mechanisms of plant survival and mortality during drought: Why do some plants survive while others succumb to drought? New Phytol. 2008, 178, 719-739.

20. Gitlin, A.R.; Sthultz, C.M.; Bowker, M.A.; Stumpf, S.; Paxton, K.L.; Kennedy, K.; Muňoz, A.; Bailey, J.K.; Whitham, T.G. Mortality gradients within and among dominant plant populations as barometers of ecosystem change during extreme drought. Cons. Biol. 2006, 5, 1477-1486.

21. Bowker, M.A.; Muňoz, A.; Martinez, T.; Lau, M.K. Rare drought-induced mortality of juniper is enhanced by edaphic stressors and influenced by stand density. J. Arid Environ. 2012, 76, 9-16.

22. NASA Earth Observatory. Earth's Energy Balance. Available online: http://earthobservatory. nasa.gov/Features/EnergyBalance/page4.php (accessed on 16 December 2013).

23. Le Treut, H.; Somerville, R.; Cubasch, U.; Ding, Y.; Mauritzen, C.; Mokssit, A.; Peterson, T.; Prather, M. Historical Overview of Climate Change. In Climate Change 2007: The Physical Science Basis. Contribution of Working Group I to the Fourth Assessment Report of the Intergovernmental Panel on Climate Change; Solomon, S., Qin, D., Manning, M., Chen, Z., Marquis, M., Averyt, K.B., Tignor, M., Miller, H.L., Eds.; Cambridge University Press: Cambridge, UK, 2007; pp. 93-127. 
24. Meehl, G.A.; Stocker, T.F.; Collins, W.D.; Friedlingstein, P.; Gaye, A.T.; Gregory, J.M.; Kitoh, A.; Knutti, R.; Murphy, J.M.; Noda, A.; et al. Climate Projections. In Climate Change 2007: The Physical Science Basis. Contribution of Working Group I to the Fourth Assessment Report of the Intergovernmental Panel on Climate Change. Solomon, S., Qin, D., Manning, M., Chen, Z., Marquis, M., Averyt, K.B., Tignor, M., Miller, H.L., Eds.; Cambridge University Press: Cambridge, UK, 2007; pp. 747-846.

25. Allen, C.D.; Breshears, D.D. Drought induced shift of a forest-woodland ecotones: Rapid landscape response to climate variation. Proc. Natl. Acad. Sci. 1998, 95, 14389-14842.

26. Beaumont, L.J.; Hughes, L.; Poulsen, M. Predicting species distributions: Use of climatic parameters in Bioclim and its impact on predictions of species' current and future distributions. Ecol. Model. 2005, 186, 250-269.

27. Rehfeldt, G.E.; Crookston, N.L.; Warwell, M.V.; Evans, J.S. Empirical analyses of plant-climate relationships for the Western United-States. Int. J. Plant Sci. 2006, 167, 1123-1150.

28. Cutler, D.R.; Edwards, T.C. Jr.; Beard, K.H.; Cutler, A.; Hess, K.T.; Gibson, J.; Lawler, J.J. Random forests for classification in ecology. Ecology. 2007, 88, 2783-2792.

29. Crimmins, S.M.; Dobrowski, S.Z.; Greenberg, J.A.; Abatzoglou, J.T.; Mynsberge, A.R. Changes in climatic water balance drive downhill shifts in plant species' optimum elevations. Science. 2011, 331, 324-326.

30. Laughlin, D.C.; Fulé, P.Z.; Huffman, D.W.; Crouse, J.; Laliberté, E. Climatic constraints on trait-based forest assembly. J. Ecol. 2011, 99, 1489-1499.

31. Covington, W.W.; Moore, M.M. Post-settlement changes in natural fire regimes and forest structure: Ecological restoration of old-growth ponderosa pine forests. J. Sust. For. 1994, 2, 153-181.

32. Covington, W.W.; Fulé, P.Z.; Moore, M.M.; Hart, S.C.; Kolb, T.E.; Mast, J.N.; Sackett, S.S.; Wagner, M.R. Restoring ecosystem health in ponderosa pine forests of the southwest. J. For. 1997, 95, 23-29.

33. Reynolds, R.T.; Sánchez-Meador, A.J.; Youzt, J.A.; Nicolet, T.; Matonis, M.S.; Jackson, P.L.; DeLorenzo, D.G.; Graves, A.D. Restoring Composition and Structure in Southwestern Frequent-Fire Forests: A Science-Based Framework for Improving Ecosystem Resiliency; General Technical Report RMRS-GTR-310; Department of Agriculture, Forest Service, Rocky Mountain Research Station: Fort Collins, CO, USA, 2013; p. 76.

34. Finkral, A.J.; Evans, A.M. The effects of a thinning treatment on carbon stocks in a northern Arizona ponderosa pine forest. For. Ecol. Manag. 2008, 255, 2743-2750.

35. Wiedinmyer, C.; Hurteau, M.D. Prescribed fire as a means of reducing forest carbon emissions in the Western United States. Environ. Sci. Technol. 2010, 44, 1926-1932.

36. Hurteau, M.D.; Koch, G.W.; Hungate, B.A. Carbon protection and fire risk reduction: Toward a full accounting of forest carbon offsets. Fron. Ecol. Envir. 2008, 6, 493-498.

37. Vegh, T.; Huang, C.H.; Finkral, A.J. Carbon credit possibilities and economic implications of fuel reduction treatements. West. J. Appl. For. 2013, 28, 57-65.

38. Sorensen, C.; Finkral, A.J.; Kolb, T.E.; Huang, C.H. Short- and long-term effects of thinning and prescribed fire on carbon stocks in ponderosa pine stands in Northern Arizona. For. Ecol. Manag. 2011, 261, 460-472. 
39. Huang, C.H.; Finkral, A.; Sorensen, C.; Kolb, T. Toward full economic valuation of forest fuels-reduction treatments. J. Environ. Manag. 2013, 130, 221-231.

40. Mason, C.L.; Lippke, B.R.; Zobrist, K.W.; Blaxton, T.D., Jr.; Ceder, K.R.; Comnick, J.M.; McCarter, J.B.; Rogers, H.K. Investments in fuel removals to avoid forest fires result in substantial benefits. J. For. 2006, 104, 27-31.

41. Snider, G.; Daugherty, P.; Wood, D. Irrationality of continued fire suppression: an avoided cost analysis of fire hazard reduction treatments versus no treatment. J. For. 2006, 104, 431-437.

42. Fulé, P.Z. Does it make sense to restore wildland fire in changing climate? Restor. Ecol. 2008, 16, 526-531.

43. Crookston, N.L.; Rehfeldt, G.E.; Dixon, G.E.; Weiskittel, A.R. Addressing climate change in the forest vegetation simulator to assess impacts on landscape forest dynamics. For. Ecol. Manag. 2010, 260, 1198-1211.

44. United States Department of Agriculture Collaborative Forest Landscape Restoration Program. Available online: http://www.fs.fed.us/restoration/CFLRP/ (accessed on 16 December 2013).

45. National Climatic Data Center. Annual Climatological Summary: 1979-2009, Flagstaff Pulliam Airport, AZ. Dataset available upon request to corresponding author.

46. Torching Index (TI) is the 20 foot wind speed necessary, in miles-per-hour, for a surface fire to ignite a crown fire [46]. Torching index is calculated in the Fire and Fuels Extension to the Forest Vegetation Simulator (FFE-FVS).

47. Van Vuuren, D.P.; Edmonds, J.; Kainuma, M.; Riahi, K.; Thomson, A.; Hibbard, K.; Hurtt, G.C.; Kram, T.; Krey, V.; Lamarque, J.; et al. The representative concentration pathways: An overview. Clim. Chang. 2011, 109, 5-31.

48. Crookston, N.L. Climate-FVS Version 2: Content, User's Guide, Applications, and Behavior. (Review Draft), 2013. Available online: http://www.fs.fed.us/fmsc/ftp/fvs/docs/gtr/ClimateFVS_ UsersGuide.pdf. (accessed on 11 December 2013).

49. Dixon, G.E. Essential FVS: A User's Guide to the Forest Vegetation Simulator; Internal Report, comp. (Revised: November 19, 2013); Department of Agriculture, Forest Service, Forest Management Service Center: Fort Collins, CO, USA, 2002; p. 226.

50. Daniels, A.E.; Morrison, J.F.; Joyce, L.A.; Crookston, N.L.; Chen, S.C.; McNulty, S.G. Climate Projections FAQ; General Technical Report RMRS-GTR-277WWW; Department of Agriculture, Forest Service, Rocky Mountain Research Station: Fort Collins, CO, USA, 2012; p. 32.

51. Breiman, L. Random forests. Machine Learn. 2001, 45, 5-32.

52. Liaw, A.; Wiener, M. Classification and regression by random forest. $R$ News 2002, 2, 18-22.

53. Rebain, S.A. The Fire and Fuels Extension to the Forest Vegetation Simulator: Updated Model Documentation; Internal Report; Department of Agriculture, Forest Service, Rocky Mountain Research Station: Fort Collins, CO, USA, 2013; p. 408.

54. Veblen, T.T.; Kitzberger, T.; Donnegan, J. Climatic and human influences on fire regimes in ponderosa pine forests in the Colorado Front Range. Ecol. Appl. 2000, 10, 1178-1195.

55. Shorter fire-return intervals in lower-elevation ponderosa pine stands are characteristic of the historic fire regimes, i.e., pre-European settlement, before widespread fire-suppression policies were implemented in the Western United States. 
56. McCusker, N. Four-Forest Restoration Initiative Coconino and Kaibab National Forests Silviculture Specialist Report; US Forest Service: Flagstaff, AZ, USA, 2013. Available online: https://fs.usda.gov/Internet/FSE_DOCUMENTS/stelprdb5413017.pdf (accessed on 16 December 2013).

57. U.S. Forest Service Four Forest Restoration Initiative. Draft Environmental Impact Statement for the Four-Forest Restoration Initiative; U.S. Department of Agriculture, Forest Service, Southwest Region: Fort Collins, CO, USA, February 2013; p. 716. Available online: http:/www.4fri.org/ pdfs/documents/NEPA/draft-eis-feb2013.pdf (accessed on 12 December 2013).

58. Four Forest Restoration Initiative Stakeholders Group. Old-Growth Protection and Large Tree Retention Strategy. Comp; Four Forest Restoration Initiative: Flagstaff, AZ, USA, 2011, (revised August 2012). Available online: http://www.4fri.org/pdfs/documents/collaboration/old_growth_ protection-revised080812.pdf (accessed on 30 November 2013).

59. Fulé, P.Z.; Covington, W.W.; Moore, M.M. Determining reference conditions for ecosystem management of southwestern ponderosa pine forests. Ecol. Appl. 1997, 7, 895-908.

60. Fulé, P.Z.; Crouse, J.E.; Roccaforte, J.P.; Kalies, E.L. Do thinning and/or burning treatments in western USA ponderosa or Jeffrey pine-dominated forests help restore natural fire behavior? For. Ecol. Manag. 2012, 269, 68-81.

61. DeGomez, T. Guidelines for thinning ponderosa pine for improved forest health and fire prevention. In Cooperative Extension: The University of Arizona College of Agriculture and Life Sciences; Publication AZ: Tucson, AZ, USA, 1397. Available online: http://cals.arizona.edu/pubs/ natresources/az1397.pdf (accessed on 24 October 2013).

62. Bailey, J.D.; Covington, W.W. Evaluating ponderosa pine regeneration rates following ecological restoration treatments in northern Arizona, USA. For. Ecol. Manag. 2002, 155, 271-278.

63. The FVS has calibrated its tree-growth equations using data primarily collected during the 20th Century [50]. The climate in North America during this period of time was relatively constant, up until the 1990s when increases in MAT became more apparent [7]. Therefore, running simulations into the 21st Century without the Climate Extension to the FVS outputs data derived from equations that assume tree-growth will not be affected by climate change.

64. Crown competition factor is a measure of area occupied by each tree's canopy [50]. A tree's crown competition factor is the percentage of an acre the tree's crown would occupy if that tree were to be grown in open conditions. A crown competition factor of 100 means that all tree-crowns would just touch. This metric is a measure of stand density and competition between trees.

65. Hurteau, M.; North, M. Fuel treatment effects on tree-based forest carbon storage and emissions under modeled wildfire scenarios. Front. Ecol. Environ. 2009, 7, 409-414.

66. Soulé, P.T.; Knapp, P.A. Radial growth rate increases in naturally occurring ponderosa pine trees: A late-20th century $\mathrm{CO}_{2}$ fertilization effect? New Phytol. 2006, 171, 379-390.

67. McDowell, N.; Allen, C.D.; Marshall, L. Growth, carbon-isotope discrimination, and drought-associated mortality across a Pinus ponderosa elevational transect. Glob. Chang. Biol. 2010, 16, 399-415.

68. Hurteau, M.D.; Stoddard, M.T.; Fulé, P.Z. The carbon costs of mitigating high-severity wildfire in southwestern ponderosa pine. Glob. Chang. Biol. 2011, 17, 1516-1521. 
69. Keith, H.; Mackey, B.G.; Lindenmayer, D.B. Re-evaluation of forest biomass carbon stocks and lessons from the world's most carbon-dense forests. Proc. Natl. Acad. Sci. 2009, 11635-11640.

70. Smith, D.M.; Larson, B.C.; Kelty, M.J.; Ashton, P.M.S. Chapter 1: Silviculture and its place in forestry. In The Practice of Silviculture: Applied Ecology, 9th ed.; John Wiley and Sons: New York, NY, USA, 1996.

(C) 2014 by the authors; licensee MDPI, Basel, Switzerland. This article is an open access article distributed under the terms and conditions of the Creative Commons Attribution license (http://creativecommons.org/licenses/by/3.0/). 